\title{
DESCRIPTION OF MOTHER'S LEVEL OF KNOWLEDGE ABOUT PLAY ACTIVITIES IN PRESCHOOL AGE CHILDREN TREATED IN THE CHILDREN'S ROOM
}

\author{
Aulia Asman ${ }^{1}$ Liza $^{2}$, Hidayati ${ }^{3}$ \\ ${ }^{1,3}$ D3 Nursing Study Program,Lecturer,Universitas Negeri Padang, Padang \\ ${ }^{2}$ Sports Science Study Program,Lecturer,Universitas Negeri Padang, Padang \\ Email: aulia.asman@fik.unp.ac.id
}

\begin{abstract}
Playing is activity could not separate from life child's whose pain and be care in hospital. When the children was brought to the hospital meet the doctor, nurse and hearting medical action, this situation make the child's worry. Worry cause of children is different, especially preschool, injury and pain cause of hearting procedure will worry cause. To minimization worried to use effective nursing planning, one of them is requirement play in hospital. Playing in hospital is parent responsibility and nurse of pediatric word. The children feel comfort and free to expression that feeling if playing accompany by parent. The important of Involvement parent, that common knowledge of patent about playing preschool. The purpose of this research are to find out descriptive of stage mother's knowledge about activity playing to child preschool who be care on pediatric word. This research used descriptive methodology design that do to mothers have preschool on pediatric word general district Hospital. The populations are 17 mothers' has preschool child who be care on pediatric word of general district hospital Padang Pariaman and technical sampling with method total sampling. Data analyses are used statistic univariat. This research result obtain knowledge stage mothers is enough $(56,45 \%)$ For that need the existence policy of hospital institution of pediatric, to add knowledge of mothers about important playing activity pediatric word and conducted playing activity to children has and do playing activity to child who be care on pediatric words.
\end{abstract}

Keywords- preschool, playing, activity

\section{INTRODUCTION}

Playing is an activity that someone does to get pleasure without considering the final result (http://www.google.com/mod, 2006). By playing children feel fun. Play is a child's need. Play is important for mental, emotional, and social health. Playing activities are one of the stimuli for optimal child development (Nursalam, 2005).

Play is an activity where children can perform or practice skills, give expression to thoughts, be creative, prepare to play a role and behave in an adult manner (Azis Alimul Hidayat, 2005). Children do not separate play and work, for children playing is all children's activities including work, pleasure and is a method of how they get to know the world (Soetjiningsih, 1995). Playing is a fun activity for children, even though it does not produce certain commodities, such as financial gain/money. Playing in children must be adapted to their growth and development. In playing, children use game tools. Play equipment for children should be adjusted to the gender and age of the child so that it can stimulate optimal child development (Nursalam, 2005).

Here, the role of parents is very much needed in motivating children to play games, and the provision of games for children must be safe, both in selection, supervision, maintenance and storage. Every parent must allow their children to play, because of the values contained in the game, including: physical values, educational values, social values, moral values, creativity values, personal values, medical values (Al-Gazira, 2001). The functions of play in children include: helping sensory and motor development, helping cognitive development, increasing children's socialization, increasing creativity, increasing self-awareness, having therapeutic value, having moral values in children (Azis Alimul Hidayat, 2005).

To achieve the play function as listed above when the child is sick or when the child is hospitalized, this play activity still needs to be carried out, but must be adapted to the child's condition. Stress in children who are hospitalized will increase. The purpose of playing in the hospital in principle is to be able to continue the optimal 
Jurnal Cahaya Mandalika, Vol. 2, No. 2, Juli 2021 ,e- ISSN: 2721-4796

Available online at: ojs.cahayamandalika.com/index.php/jcm

Copyright @ 2021 Published by: Institut Penelitian \& Pengembangan Mandalika Indonesia

growth and development phase, develop children's creativity and children can adapt more effectively to stress (Nursalam, 2005). Being hospitalized is a traumatic experience for children. One of the causes of stress in children is hospitalization. Hospitalization is a complex experience for children. When the child is taken to the hospital, he meets the doctor and nurse who are strangers to the child. In the hospital, children have to face an unfamiliar environment, unknown caregivers and disruption to their lifestyle (Whaley and Wong's, 2003).

The meaning of illness and hospitalization in children is different, according to their growth and development. The negative result of hospitalization is that the child will experience anxiety. The anxiety caused by hospitalization is separation, loss of control and bodily injury and pain. In infants and toddlers, the main anxiety is caused by separation from their parents, whereas in preschoolers the anxiety is about bodily injury and pain from painful procedures. (Mary E. Muscari, 2005).

Children are individuals who are in a range of developmental changes starting from infancy to adolescence. Childhood is a period of growth and development starting from infancy ( $0-1$ years), toddler age (1-2.5 years), preschool (2.5-5 years), school age (5-11 years), to adolescence (11-18 years). In the process of developing children have physical characteristics, cognitive, self-concept, coping patterns, and social behavior (Azis Alimul Hidayat, 2005). (Asman, et al, 2020). According to Suryanah (1996) the preschool period is a time of transition between infancy and childhood. Preschool children have mastered gross and fine motor skills, and have developed communication skills both verbally and non-verbally. According to Erikson's theory, at the preschool stage, children develop initiative versus guilt after successfully instilling a sense of trust and autonomy that developed in the previous stage (Achir Yani Syuhaimie Hamid, 1999). What preschoolers say are ages 3 to 6 years, healthy preschoolers are lean, cheerful and agile and have good posture, gross motor skills are getting better while fine motor skills show major developments as indicated by increased drawing skills (Mary E. Muscari, 2005).

An effective care plan for a child being cared for must be based on identifying the needs of the child in the family. The nursing plans are as follows: preparing children for hospitalization, preventing or minimizing the impact of separation, minimizing feelings of loss of control, preventing or minimizing bodily injury, pain management, fulfilling play needs, maximizing the benefits of hospitalization (Nursalam, 2005). Especially the feeling of trauma in an incident that seemed scary to him (Asman, et al,2020). One of the nursing plans above is to meet the playing needs of children who are hospitalized. According to Marilyn M. Friedman (1998)

One of the nursing plans above is to meet the play needs of children who are hospitalized. According to Marilyn M. Friedman (1998) one of the tasks of family development with preschool-aged children is to meet the needs of family members such as a home, playroom, privacy, security. In playing games, preschoolers prioritize socialization with peers. Games in preschool age children are associative (interactive and cooperative). Examples of games for preschoolers are big blocks, puzzle games, crayon pencils, hand puppets, doctor and nurse equipment, and others. In the implementation of playing activities in hospitals, it is necessary to pay attention to the principles of playing and games that are in accordance with the age or level of growth and development of children, so that the purpose of playing, namely to maintain the process of growth and development, can be achieved optimally (Asman, et al,2020). In addition, parental involvement in play activities is very important because children will 
feel safe, so that they are able to express their feelings freely and openly. With the involvement of parents in playing activities for children, here the importance of parental knowledge in meeting the needs of children, one of which is playing. Even though the child is hospitalized, this play activity is still carried out. One of the goals of playing in the hospital is that children can adapt more effectively to stress (Nursalam, 2005).

From the results of a preliminary study conducted by researchers on 25 respondents in the children's room of Padang Pariaman Hospital, based on interviews and observations of researchers with respondents, none of the respondents brought toys for their children who were hospitalized and the respondents lacked knowledge about meeting their needs. playing with children who are hospitalized, and lack of knowledge of game tools that are appropriate for the child's growth and development or the child's age (Asman, et al. 2020). Based on the initial study, researchers also found that the anxiety felt by the treated children was mostly due to changes in the new environment or environment and the actions taken by the medical team and the medical staff as well as the lack of initiative by these mothers to entertain their children such as inviting them to play and giving games that are appropriate for the child's age or child's growth and development.

Based on the description above, the researcher is interested in knowing more about "The Description of Mother's Knowledge Level About Play Activities in Preschool Age Children Treated in the Children's Room of Padang Pariaman Hospital.

\section{RESEARCH METHOD}

This research used descriptive methodology design that do to mothers have preschool on pediatric word general district Hospital. The populations are 20 mothers' has preschool child who be care on pediatric word of general district hospital Padang Pariaman and technical sampling with method total sampling. (Nursalam, 2003).

\section{FINDINGS}

1. Overview of Respondents Education Level

Table. 1

Frequency Distribution of Respondents Education Level

\begin{tabular}{|c|c|c|c|}
\hline No & Level of Education & $\mathbf{f}$ & $\boldsymbol{\%}$ \\
\hline 1 & SD & 6 & 29,41 \\
2 & SMP & 6 & 29,41 \\
3 & SMA & 8 & 41,18 \\
\hline & Amount & 20 & 100 \\
\hline
\end{tabular}

Source: primary data

Based on the table. 1 above 8 respondents have high school education (41.18\%), 6 respondents have junior high school education $(29.41 \%)$ and 6 respondents have elementary education $(29.41 \%)$.

\section{Description of Respondent's Knowledge Level}


Table. 2

Frequency Distribution of Respondents' Alternative Answers About

Playing Activities For Preschool-Aged Children Treated in the Children's Room Padang Pariaman Hospital

\begin{tabular}{|c|c|c|c|}
\hline No & Kriteria & $\mathbf{f}$ & \% \\
\hline 1 & Good & 6 & 29,41 \\
2 & Enough & 8 & 41,18 \\
3 & less & 6 & 29,41 \\
\hline & Jumlah & 20 & 100 \\
\hline
\end{tabular}

Source: primary data

Based on the table. 2 above, the respondent's knowledge about playing activities in preschool-aged children includes the notion of playing in children, the function of playing in children, the values contained in the game, various games and their benefits for the development of the child's soul, understanding of preschool-aged children, examples of game tools. preschool age children, examples of games for preschool age children, the purpose of playing in the hospital, the principles that need to be considered in the implementation of playing in the hospital, the efforts that need to be considered in the implementation of playing in the hospital, playing in the hospital in general the level of knowledge of the respondents in enough category $(41.18 \%)$ good (29.41), less $(29.41 \%)$.

Based on the research results shown in the table. 2 for respondents' knowledge about play activities in preschool-aged children who are treated in the children's room at Padang Pariaman Hospital which includes the understanding of playing in children, the function of playing in children, the values contained in the game, various kinds of games and their benefits for the mental development of children, understanding of preschool age children, examples of play equipment for preschool age children, examples of games for preschool age children, the purpose of playing in hospitals, principles that need to be considered in the implementation of playing in hospitals, efforts that need to be considered in the implementation of playing in hospitals, playing in hospitals hospitals in general the level of knowledge of respondents in the category enough (41.18\%), good (29.41\%), less $(29.41 \%)$.

From the respondent's identity data, it is known that the education level of the respondents is about 8 respondents with high school education, 6 respondents with junior high school education, 6 respondents with elementary education and no respondent with DIII or SI education. Looking at the education of the respondents, who are the majority of high school students, this will affect the respondents' knowledge about playing activities in preschool age children, because the higher a person's education, the higher the knowledge they have, because the easier it is to find information. Sufficient knowledge of respondents about playing activities in children, is also due to the lack of information obtained by respondents about playing with children. Respondents also saw that there was no play room for preschool-aged children who were treated in the children's room and there were no scheduled play activities for children who were cared for in the nursery

This is in accordance with the opinion of Notoatmodjo (2003) that knowledge increases with frequent exposure to something that is often done and also knowledge 
obtained from experience or other people who arrive at someone. The lack of information obtained by respondents regarding playing activities in preschool age children is due to the lack of motivation and interest of respondents to read sources from both print and electronic media because the respondents are busy with household work, so that parenting patterns for children's growth and development are one of them. the need for children to play in children is neglected. To form one's knowledge apart from educational factors are also influenced by several other factors as described by Notoatmodjo (2003), namely motivation, interests and talents. This all arises because of the urge to give the best in meeting the needs of the individual himself

Based on the table. 2 above 6 respondents who have good knowledge $(29.41 \%)$. This is because these respondents often see and hear that one of the needs of children, namely playing and playing, cannot be separated from children's lives. According to Suparlan Suhartono (2005) one of the sources to gain knowledge is the Pancaindra (Indriawi experience). With eyes and ears people can witness firsthand the truth of an object. In table 2 above, a small number of respondents have a low level of knowledge. This is also influenced by the education of the respondents.

Based on the data above, it is necessary to increase the knowledge of respondents to find information about playing activities in preschool-aged children who are treated in hospitals. This information can be obtained by respondents through health education about playing activities in preschool-aged children who are treated in hospitals, print media and electronic media. In addition to the information mentioned above, respondents can also obtain information from health workers. With the motivation of respondents to look for related sources such as often reading books, watching television, etc., the knowledge gained by respondents is getting higher. The low level of respondents' knowledge about play activities in preschool-aged children who are hospitalized is influenced by interest and motivation, it turns out that respondents' knowledge about play activities has a very important role in meeting the playing needs of preschool-aged children who are treated

\section{REFERENCE}

Arikunto, Suharsimi, (2002). Prosedur Penelitian Suatu Pendekatan Praktek. Jakarta: PT. Rineka Cipta

Asman A, Hidayati, Anggia Sari DH, (2020). The Effect of Boiling Water of Paper Crocatum Leaves To the blood sugar levels on patients Diabetes Mellitus Type 2 in the work area of andalas PHC Padang |https://jurnal.syedzasaintika.ac.id. Proceeding International Conference Syedza Saintika. vol 1.no 1.

Asman, A., Fatimah, S, (2020). Implementation of Universal Awareness in Management of Hospital Environment as A Business for Prevention of Nosocomial Infections in Pariaman Regional General Hospital Science and Environmental Journals for PostgraduateVol. 2 No. 2 (pp. 14-23) June 2020p_ISSN 2655-5085e_ISSN 2655-5239. http://senjop.ppj.unp.ac.id/index.php/senjop

Asman, A., Asman, A., Alfina, R., The Model of Trauma Healing Policy for

The Tsunami Disaster Mitigation in Padang, Indonesia. Sumatra Journal of Disaster, Geography and Geography Education, December, 2020, Vol. 4, No.
2, $\quad p p$.
212-219
Disaster,
Geography,
Geography 
Jurnal Cahaya Mandalika, Vol. 2, No. 2, Juli 2021 ,e- ISSN: 2721-4796

Available online at: ojs.cahayamandalika.com/index.php/jcm

Copyright ( 2021 Published by: Institut Penelitian \& Pengembangan Mandalika Indonesia

ducation,http://sjdgge.ppj.unp.ac.id/index.php/Sjdgge ISSN : 2580 - 4030 ( Print ) 2580 - 1775 ( Online), Indonesia

Asman, A., Barlian, E., Fatimah, S., Dewata, I., Asman, A., Model of Trauma Healing Policy For Communities in the COVID-19 Pandemic Period in Padang City-Indonesia. Jour of Adv Research in Dynamical \& Control Systems (JARDCS), Vol. 12, 07-Special Issue, 2020

Budiarto, Eko, (2001). Biostatistik Untuk Kedokteran dan Kesehatan Masyarakat. Jakarta: EGC

Engel, Joyce, (1998). Pengkajian Pediatrik. Jakarta: EGC

Friedman, Marilyn, M (1998). Keperawatan Keluarga. Jakarta: EGC

Gazira, Al, (2001). Seni Mendidik Anak. Jakarta: Pustaka Al Kautsar

Hamid, Achir Yani Syhaimie, (1999). Buku Ajar Asuhan Keperawatan Kesehatan Jiwa pada Anak dan Remaja. Jakarta: Widya Medika

Hardiono, (2001). Mainan dan Permainan. PT Sarana Kinasih Satya Sejati.

Hidayat, Aziz Alimul, (2005). Pengantar Ilmu Keperawatan Anak I. Jakarta: Salemba Medika

Muscari, Mary E, (2005). Perawatan Pediatrik. Jakarta : EGC

Notoatmodjo, Soekidjo, (2005). Metodologi Penelitian Kesehatan. Jakarta:PT. Asdi Maharatya. , (2003). Ilmu Kesehatan Masyarakat. Jakarta: IKAPI

Nurkencana, Wayan (2001). Perkembangan Jasmani dan Kejiwaan. Jakarta: Usaha Nasional

Efendi, Nasrul (1998). Dasar-Dasar keperawatan Kesehatan Masyarakat. Jakarta: EGC

Nursalam, (2005). Asuhan Keperawatan Bayi dan Anda. Jakarta: Salemba Medika

, (2003). Konsep dan Penerapan Metodologi Penelitian Ilmu Keperawatan, .Jakarta: Salemba Medika

Sacharin, Roza, M, (1996). Prinsip Keperawatan Pediatrik. Jakarta:EGC

Soetjiningsih, (1995). Tumbuh Kembang Anak. Jakarta: EGC

Suryanah, (1996). Keperawatan Anak untuk Siswa SPK. Jakarta: EGC

Suhartono, Suparlan, (2005). Filsafat Ilmu Pengetahuan. Yogyakarta: Ar-ruzz Media

Pengaruh Permainan pada Perkembangan Anak, (2006), (www.info_balitacerdas.com, dikutip pada 10 Juni 2006 jam. 16.00 WIB) 